\title{
Training Provision by Firms and the Scope of Collective Bargaining: An Empirical Analysis Using a Large Firms Panel from Spain*
}

\author{
Miguel Á. Malo** \\ Universidad de Salamanca, Spain \\ Nuria Sánchez \\ Universidad de Cantabria, Spain
}

\begin{abstract}
In this article we analyse how labour market imperfections affect training hours using a firms panel from Spain. In fact, we use the scope of collective bargaining as a proxy for the relative strength of organized labour because of the Spanish institutional framework. We find a clear and relevant positive effect of collective agreements at the firm level on training, measured as hours lost from work and devoted to training. As this type of collective agreements is also associated with higher wage compression we interpret this result as supporting the Acemoglu-Pischke model on training in imperfectly competitive labour markets.

* The data used in this paper were provided by the Social and Labour Statistics Office from the Spanish Ministry of Employment and Social Affairs. We are indebted to Carmen Salido for her assistance and patience with our requests.

** Author for correspondence: Miguel Á. Malo. Dept. of Economics. Universidad de Salamanca. Campus 'Miguel de Unamuno'. E-37007 Salamanca (Spain) E-mail: malo@usal.es. Tel.: +349232946 40. Fax: +34923294686.
\end{abstract}


Keywords: unions; firm-level agreements; wage compression; imperfectly competitive labour markets

JEL Classification: J23, J24, J31

\section{INTRODUCTION}

The main objective of this article is analyzing how the scope of collective bargaining affects the amount of training hours in firms. As we are using Spanish data, the scope of collective bargaining will be a proxy for the varying strength of organised labour in firms because of the institutional framework of the Spanish labour market. The existence of a collective agreement at the firm level means that workers are organised to defend their interests (usually joining unions but not in all cases). The main reason is that there are no workers without collective bargaining coverage because of the erga omnes principle of the Spanish Labour Law. Therefore, differences come from the different scopes of the collective agreements: establishment or firm agreements versus above firm-level agreements. The influence of the scope of collective bargaining will inform us about the relative influence of organised labour on training. Along these lines, a relevant novelty of this article is that it considers the institutional framework of the labour market explicitly when analysing the impact of organized labour on training.

A relatively recent line of economic research — represented by Acemoglu and Pischke (1998 and 1999a) — has developed models whereby it is possible to understand the amount of human capital investments when labour markets are imperfectly competitive. In particular, when labour market frictions reduce the wages of skilled workers when compared to wages of unskilled workers, firms may provide and pay for general training, which is a contradiction of the traditional statement of Becker (Becker, 1975). The compression of the wage structure may induce firms to provide and pay for general training and, therefore, some typical labour market institutions (such as trade unions) causing wage compression may increase one of the components of human capital investment, and even contribute to total human capital accumulation. Given that in the Spanish institutional framework, collective bargaining at the firm level is a proxy for a greater presence of organised labour in firms (and following Canal and Rodríguez, 2004, these firms have a significantly higher wage compression), we should observe more training hours financed by firms with respect to firms covered by agreements of higher levels, and this will be the main prediction to be tested in the empirical analysis. Therefore, our article should be considered as part of the growing literature about 
the effects of the market structure (here in terms of the institutional framework of the labour market) on training provision.

The database used in this article is the Encuesta de Coyuntura Laboral (ECL) or the Survey of Economic Situation, launched by the Spanish Ministry of Employment. The ECL is a quarterly longitudinal survey on firms which obtains information on stocks and worker turnover at the establishment level, and, of course, the scope of the collective bargaining and the amount of working hours lost because of training (in hours). For the purpose of this study, we use data on establishments having 500 or more workers during the period $1 / 1993-1 / 2002^{1}$.

The remainder of the paper is as follows. In the second section, we briefly present the literature on the influence of unions on training. We also discuss the importance of the scope of collective bargaining in Spain and of the previous work showing that the relative effects of bargaining at firm level are in along the same lines of union membership in other institutional frameworks. In the third section, we describe the main features of the data base and present the empirical analysis. The last section summarizes the main results of the article.

\section{TRAINING, UNIONS AND THE SCOPE OF COLLECTIVE BARGAINING}

\subsection{Unions and Training}

The effect of unions on training can be direct or indirect. A direct effect would be the result of an explicit union strategy to increase the human capital of its affiliates. Some reasons to adopt such an objective would be to increase wages and chances for promotion inside the firm, because usually a higher investment in training is related to a more successful career and better results in internal labour markets. A higher investment in specific training could be beneficial for the worker even considering a job change outside the firm when training is 'portable' or 'visible' thanks to a certificate. Those workers dismissed during a recession will have better prospects of being re-hired by other firms if they can prove, with a certificate, that under normal circumstances they were so valuable to their previous firms as to deserve specific training. Ceteris paribus, such certificate would be a positive characteristic to take into

1 This is the only stratum of establishments for which detailed longitudinal information on gross flows of workers is made available. 
account in the job search. Authors, such as Rainbird (1990), stress that the declining trend in union membership has led some unions to enhance the quality and quantity of training as a way of making themselves more attractive to workers. In Spain, unions are involved in national pacts with employers' organisations (and sometimes the government) to finance workers training ${ }^{2}$, in special continuous training. See, for example, Rigby (2002) for a study on the role of unions in the provision of continuous training in Spain.

The indirect effects of unions on training are potentially related to the effects of unions on the level and structure of wages, and on labour turnover. In this vein, Mincer (1983) proposed that as unions reduce labour turnover and increase wages and fringe benefits, employees will be discouraged from investing in general training. However, as unions reduce turnover, the incentives for the firm to invest in specific training will increase. Therefore, the Mincer hypothesis was that the effect on total human capital accumulation is ambiguous (the decrease in general training is not necessarily equal to the increase in specific training), but unambiguously unions would increase specific training. In spite of the Mincer hypothesis, until very recently the most common belief among economists was that unions, through their effects on wage compression, reduce investments in human capital ${ }^{3}$ (Lindbeck et al., 1993). On one hand, we have research on the US labour market confirming a negative influence (see, among others, authors Duncan and Stafford, 1980, and Barron et al., 1987). On the other hand, we have other works from other labour markets and they frequently find a positive union influence on training. See Arulampalam and Booth (1998), Green (1993), Green et al. (1999), and Booth et al. (2003) for the UK, and Kennedy et al. (1994) for Australia. Some authors even find a positive influence for the US, as Lynch (1992), Veum (1995), Osterman (1995) Frazis et al. (1995).

\footnotetext{
${ }^{2}$ However, sometimes such strategies have been cited as being an indirect way of obtaining additional funding for the bureaucratic structure of unions and employers' organisations rather than an investment in training with significant returns for workers. See Martínez-Lucio and Stuart (2003) for a review about how Spanish unions and employers' organizations have progressively included training as part of their organizational strategies.

${ }^{3}$ A theoretical prediction of a negative (but indirect) effect is provided by Ryan (1991) [quoted by Green (1993)]. If unions successfully press the firms to establish a wage mark-up for trained workers, then they raise the costs of training for the firm, giving incentives to the firm to invest less in training. The model is based on asymmetric information and uncertainty about the costs and quality of training inputs.
} 
Recently, Acemoglu and Pischke (1998; 1999a; 1999b) have brought up the issue of training in imperfectly competitive labour markets, providing a theoretical reasoning for a positive influence of labour market institutions on training through increases in wage compression. According to these authors, if labour market imperfections compress wages structure, firms may provide and pay for general training. The rationale for this unexpected result under the traditional human capital theory is due to labour market imperfections (in this case, unions). The labour market imperfections would cause trained workers not to obtain their marginal product when they change jobs, converting general skills into specific ones. The Acemoglu-Pischke model proposes that firms will have incentives to invest in general training for their workers ${ }^{4}$. This result leads Acemoglu and Pischke (1999a) to affirm that total training investment in imperfect labour markets might be even greater than in competitive labour markets. Booth and Zoega (2004) have generalized the Acemoglu-Pischke model showing the different impact of changes in absolute and relative wage compression, and they argue that, although relative wage compression is not a necessary condition for the firms' willingness to pay for general training, it does increase the firms' incentives to pay for workers' general training. ${ }^{5}$

To sum up, we have a 'received wisdom' considering a negative effect of unions on training to be more likely, although there are some theoretical models (and some empirical articles) alleging that this effect would be positive on some components of training, especially on general training, when labour market 'frictions' are associated with wage compression. Therefore, it is an empirical question whether organised labour has a negative or a positive effect on training or not, although confirming the existence of wage compression associated with the alleged 'labour market friction' became crucial in supporting predictions of the Acemoglu-Pischke model.

\footnotetext{
${ }^{4}$ Previously, other authors such as Green (1993) had included intuitive explanations in the same way in order to explain that employers bear a substantial proportion of the costs of general training.

${ }^{5}$ In addition, the exit-voice theory proposed by Freeman (1980) provides additional support for a positive relationship between unions and training, inducing firms to provide general training for their employees. Following Green (1993) as the voice effect of unions decreases turnover, the cost of training investment will be lower in unionised firms, and, in addition, one aspect of the management response to the union voice may be closer attention to training needs. García-Serrano and Malo (2002) have shown that collective agreements at the firm level are associated with voice effects such as lower turnover and quit rates, and higher dismissal rates (with respect to above levels of collective bargaining).
} 


\subsection{What does the scope of collective bargaining mean in Spain?}

The Spanish case provides an interesting context for this empirical analysis because of the peculiarities of the Spanish institutional framework. In Spain, all workers are de facto covered by a collective agreement because of the erga omnes principle of the Spanish Labour Law ${ }^{6}$. This principle ensures the ex-ante application of the conditions established the parties in the collective bargaining at each level to every worker. Therefore, although far from all workers being affiliated a union, all workers are covered by the agreements of some worker' representatives and the respective employers' organisations. Therefore, in Spain the difference between unionised and non-unionised workers is not relevant and membership is mainly explained by such ideological reasons as feeling closer to a left-wing ideology (Rodríguez, 1996). The differences come from the different levels of the collective bargaining.

In Spain, there are multiple levels of bargaining: national economy-wide bargaining (only used in the eighties); industry-level bargaining between the representatives of employers' associations and workers associations resulting in industry agreements whose geographical scope might be the whole nation but is usually the province; and finally firm-level bargaining between employer and worker representatives.

Unions and employers' organizations decide the level of bargaining, not the State $^{7}$. Unions and employers' associations encourage industry and above firm-level agreements where their ability to impose organizational objectives is greater than at the firm/ plant level. In fact, most workers depend on province-industry level agreements. The firm (or plant) level can have two types of worker representatives: the groups of unionized workers in the establishment (in Spanish, secciones sindicales) and the works councils (comités de empresa). The works councils can only exist in firms with 50 employees or more, and have enjoyed an important prestige among workers in Spain

${ }^{6}$ For the details of the Spanish legal framework on unions and collective bargaining see, for example, Jimeno and Toharia (1993) or Martínez Lucio (1998). For a general statement about unions and training in Spain (but not focusing on the relevance of the scope of collective bargaining) see Rigby (2002).

${ }^{7}$ However, usually for collective bargaining above the firm level there is not an explicit choice of the level of bargaining. Then, the level is simply the level of past negotiations, and many times the geographical distribution of collective bargaining is very similar to the restricted and very limited collective bargaining of the Francoist dictatorship (when free unions where simply banned). 
since the early 1980s. Both of them can be worker representatives in the collective bargaining at the firm level, although the scarce data available show a greater importance of works councils as workers' representatives ${ }^{8}$ (see, for example, Jimeno and Toharia, 1993, or Malo, 2005).

An eventual problem linked to this structure of collective bargaining is the possibility of successive negotiations from higher to lower levels. If wage increases obtained at above bargaining levels are taken as given, then successive agreements at lower levels will increase wages up to the firm-level where we should observe the highest wages. Spanish literature on bargained wages confirms that workers covered by a collective agreement at the firm level enjoy higher wages than the rest of workers (see, for example, Abellán et al., 1997). However, a deeper analysis of the Spanish collective bargaining shows that some industries (such as construction or the chemical industry) are specialized in sectoral agreements, while others (such as electricity distribution or the automobile industry) are specialized in firm-level agreements, and, in fact, concurrence of agreements of different levels only affects a maximum of 12 percent of the total workers (Fina et al., 2001) ${ }^{9}$.

Considering the different levels of collective bargaining in Spain, the firm level means an organised presence of unions in the firm and/or a bargaining capability of the works councils in firms with 50 or more employees. Previous research has confirmed that the role played by firm level agreements is similar to union coverage in American or British labour markets. In this way, García-Serrano and Malo (2002) find evidence about a typical voice effect in those firms with this type of collective agreements; decreasing total turnover and quit rates, and increasing dismissal rates. In addition, Canal and Rodríguez (2004) confirm that in Spanish firms with firm-level bargaining there is a higher wage compression than in those firms with recognised unions in the United Kingdom or in the United States. Canal and Rodríguez (2004) show that, using descriptive information, agreements at the firm level in Spain show greater wage

\footnotetext{
${ }^{8}$ Usually unionized workers of the establishment are the most common members of the works councils. However, many 'independent' workers are members of works councils (and, probably, this is part of the social prestige of this institution among workers). For further details about Spanish works councils see, for example, Escobar (1995).

${ }^{9}$ In addition, some authors (such as Jimeno, 1992) have observed a sort of specialization by levels. Bargaining at the industry level is almost exclusively focused on wages and working hours, while firm-level bargaining (almost exclusively in large firms) is more detailed and includes (in addition to wages) agreements on absenteeism, productivity, etc., although explicit bargaining over employment is rarely observed.
} 
dispersion: the log of the standard deviation of gross hourly wage is 5.797 for firms with a collective agreement at the firm level and 5.151 for firms with a sectoral agreement (Canal and Rodríguez, 2004, Table A.5). However, this difference responds to a composition effect in the intra-firm wage dispersion. When these authors estimate the determinants of wage dispersion and the decomposition of wage dispersion using the traditional Oaxaca-Blinder methodology, they find that collective agreements clearly reduce gross wage dispersion. This negative effect ranges from $19.8 \%$ to $53.3 \%$ (Canal and Rodríguez, 2004, Table 4) depending on the wages structure taken as reference in the Oaxaca-Blinder decomposition (the first one corresponds to the reference of firms with a collective agreement at the firm level and the second one to firms with a sectoral agreement).

Note that the existence of labour market friction not being sufficient for firm investment in additional general training, following the Acemoglu-Pischke model, is incorrect. Such friction should be related to a compression of the wage structure, as it is for Spanish collective agreements at the firm level. In this vein, in Spain this wage compression corresponds to an explicit strategy of Spanish unions to care less for skilled than for unskilled workers (Dolado et al. 1999; Rodríguez, 2001; Bover et al., 2002), which corresponds to the Acemoglu-Pischke requirement that the compression of the wage structure must be greater for more skilled workers.

Therefore, we expect that where firm-level bargaining exists there will be an increase in training, because it is a channel for the direct intervention of organized labour and its documented effect on firms' wage compression. The existence of such an effect on training would improve the knowledge regarding the impact of workers' representation institutions beyond the institutional contexts characterised by the dichotomy between unionized and non-unionised firms (because in the Spanish case, by definition, all firms are covered by a collective agreement and, therefore, there are no 'non-unionised' firms).

\section{EMPIRICAL ANALYSIS}

\subsection{Description of the Database and Main Variables}

The data for this research comes from the Encuesta de Coyuntura Laboural (ECL) or Survey of Economic Situation. The ECL is a longitudinal survey carried out on a quarterly basis since the second quarter of 1990 by the Spanish Ministry of Labour and Social Affairs. In 1997, the ECL underwent important methodological changes involv- 
ing the inclusion of establishments with fewer than 5 workers in the survey sample along with a new sample stratification methodology. The ECL considers the following groups of plant size: 1-2, 3-5, 6-10; 11-25; 26-50; 51-100; 101-250; 251-500; and more than 500. The total sample consists of about 12,000 establishments. The survey covers non-agriculture industries but excludes the public administration, military forces, social security, diplomatic delegations, and international and religious organisations from the service sector. An interesting feature of the data set is that it is a census for firms with 500 employees or more, the number of such large firms being around 1,000 in a given quarter ${ }^{10}$.

In particular, this paper uses quarterly information on these large firms for the period 1997:1-2002:1. Although the major methodological change introduced in the first quarter of 1997 does not affect the stratum of establishments with 500, it is only from this quarter that we have information on training suitable for our analysis.

In addition, establishments which have answered the questionnaire in some but not all of the quarters of the period 1997:1-2002:1 have also been selected. These characteristics of the sample allow us to build a non-balanced panel of establishments, which represent around 15 percent of total non-agriculture employment ${ }^{11}$. The number of observations is 24,664. The average size of firms is 1,247 workers and the maximum is 19,922 .

To determine the scope of the collective bargaining, the ECL questionnaire asks the establishments which type of agreement they have. The possible answers are as follows: bargaining at a plant or firm level; and bargaining at an above level (industry, province, regional or national). Table 1 shows that 33 per cent of the sample has plant/ firm-level collective agreements.

Our training variable is obtained from the part of the questionnaire devoted to lost working hours because of different reasons. One of them is because of workers attending training courses (either general or specific) during working hours. Training hours outside of work time, even when they are funded by the firm, are not included in the sur-

${ }^{10}$ Those establishments whose workforce has occasionally fallen below 500 in any of the quarters remain in the sample.

${ }^{11}$ This employment share is consistent with that coming from other sources. For instance, the Structure, Consciousness and Class Biography Survey (Encuesta de Estructura, Conciencia y Biografía de Clase, ECBC), carried out in 1991, shows that the employment share of private firms with 1,000 employees or more was 10 percent. The Working Conditions Survey (Encuesta de Calidad de Vida en el Trabajo, ECVT), carried out in 2001, indicates that some 21 percent of non-agriculture employment corresponds to firms with 500 or more workers. 
vey. Therefore, we have a down-biased estimation of total training received by workers. However, training measured by our variable represents a relevant cost to firms because it is defined as lost working hours. Firms are assuming a relevant opportunity cost because of this training. Then we are capturing a part of the training whose costs are, at least partially, assumed by the firm. A final characteristic of this variable is that we cannot distinguish whether training is general or specific. As this training is at least partially funded by firms, according to Becker, this training should be exclusively specific, but following Acemoglu and Pishcke our training variable might contain general training. However, if our training variable is not affected by the different levels of collective bargaining, our variable would only include specific training because we would have obtained a refutation of the Acemoglu-Pischke prediction in the Spanish institutional framework. A positive result would be in line with the Acemoglu-Pischke model, because collective agreements at the firm level would increase training funded (at least partially) by the firm. ${ }^{12}$

As we have the amount of training hours we can build two different versions of the training variable. The first is regarding the level of training hours per 100 workers per quarter. This is an indicator of the intensity of training activities in each firm. On average, establishments devote 59.6 training hours per 100 workers per quarter (see Table 1). The second one is a dichotomous variable where 1 refers to giving any training to their workers in the quarter and 0 means that firm does not give training at all to its workers in the quarter. This measure gives us information about the involvement of firms in training activities. Almost 28 per cent of establishments have a positive amount of training hours (see Table 1).

For the sake of simplicity, in Table 2 we have aggregated the distribution of hours of training per worker in the following groups: establishments without training in the quarter; establishments with less than 100 hours per worker in the quarter; establishments with more than 100 hours per 100 workers. The threshold of 100 hours has been chosen because of the distribution shape of training hours. Figure 1 shows this distribution and we can see that above this threshold the number of firms decreases but we have a large enough size for this group (2,878 observations) to disaggregate by some categories.

Table 2 confirms that the scope of collective agreements is related to training hours. For firms which have zero training hours, the proportion of firms with collective agreements at

${ }^{12}$ A positive result might be coherent too with the exit-voice theory. However, to our knowledge, the exit-voice theory does not contain an explicit prediction about wage compression as does the Acemoglu-Pischke model, which is also observed for agreements at the firm level as we showed in section 2.2. Therefore, the Acemoglu-Pischke model would provide a more comprehensive interpretation of a positive influence of agreements at the firm level on training provision. 
the firm level is much lower than those that have agreements of a higher? an above level (29.6 per cent compared to 70.4). This result is coherent with previous descriptive results for Spain presented by Abellán et al. (1997) showing that firm agreements are correlated with more training. Table 2 also shows that a higher number of training hours is related to a higher share of establishments covered by collective agreements at the firm level, 36.6 per cent for firms with fewer than 100 hours and 53.8 per cent for those above 100 hours.

Finally, as some authors (for example, Arulampalam and Booth, 1998, for the UK, or Albert et al., 2005, for the Spanish case) have stressed that increasing flexibility using atypical contracts can negatively affect training, we have considered the proportion of workers with temporary contracts as well as the proportion of workers with full-time contracts. Table 2 shows that those establishments with more training hours have a lower proportion of workers with temporary or part-time contracts. While establishments without training have 88.2 per cent of full-time workers, those establishments with less than 100 training hours per 100 workers have 93.3 per cent and those with 100 or more training hours per 100 workers reach 96.7 per cent. On the other hand, temporary contracts in establishments without training represent 31.8 per cent of the total workforce, but in establishments with less than 100 training hours per 100 workers this proportion decreases to 26.9 and even to 16.9 in establishments with 100 or more training hours per 100 workers. Therefore, the descriptive analysis confirms the usual presumption that when firms use more atypical contracts training is negatively affected.

\subsection{Econometric Analysis}

As we have two versions of the training variable, we will estimate a probit and a tobit model. In the probit model the dependent variable has only two values: 0 for those firms without training in a given quarter, and 1 for those firms with positive training hours in a given quarter. The rationale is to analyze the determinants of having training hours rather than the size of training hours. As our survey is a panel we have estimated a random-effects probit model.

The econometric model used to analyze the determinants of the size of training hours is a tobit model. As firms have zero or more training hours, and zeros have a clear meaning (no training at all in the firm at a given quarter) our dependent variable has a tobit form. As we have panel data, we estimate a random-effects tobit model ${ }^{13}$.

${ }^{13}$ As we have used Stata 9.0 to estimate both models, we have checked whether the default number of quadrature points of the estimation affects the results or not. We have obtained very sta- 
In both models, the independent variables are the establishment characteristics which can be constructed from the information provided in the ECL database, and they are defined in Table 1. They are a time trend, the proportion of part-time workers, a set of industry dummies, the proportion of temporary and fixed-term workers, turnover ${ }^{14}$, a set of regional dummies, and three dummies of the firm's size.

Our main variable of interest is the scope of collective bargaining because it is the proxy for the presence of organized labour in the establishment, as we have explained above.

In the probit model (Table 3), we see that the existence of bargaining at the firm level has a positive influence on having training hours and the estimation of the correspondent marginal effect (Table 4) shows that having collective agreements at the firm level increases the probability of having training in the firm by 11.4 per cent. Therefore, agreements at firm level increase training hours and this training is, at least partially, funded by the firm. The tobit model (Table 5) also presents a positive coefficient. In firms with a collective agreement at the firm level, training increases around 1.5 hours per 100 workers ${ }^{15}$.

It is important to note that firms that engage in firm level agreements may have some specific management strategies more prone to develop training funded by the firm. Not considering this unobserved heterogeneity would inflate the estimated impact of internal bargaining on training. In addition, there is no information in our database about some characteristics of the workers (such as age or educational level, for ex-

ble results especially for the variable capturing the scope of collective bargaining. In general, the rest of variables were very stable too, with the exception of the dummies related to the firm's size. Therefore, the estimated effects for the firm's size are less confident than the rest of effects.

${ }^{14}$ We have defined worker turnover as the total gross worker turnover following García-Serrano and Malo (2002), who follow Davis and Haltiwanger (1992). Given the size of establishment $i$ at times $t\left(E_{i, t}\right)$ and $t-1\left(E_{i, t-1}\right)$, the average size of establishment $i$ between $t-1$ and $t$ is defined as follows: $N_{i, t}=\left(E_{i, t}+E_{i, t-1}\right) / 2$. By aggregating, it is possible to obtain the size of the whole economy: $N_{t}=\Sigma_{i} N_{i, t}$. The hiring (separation) rate is defined as the proportion of the number of workers arriving in (leaving) establishments between $t-1$ and $t$ with respect to the employment stock: $h_{i, t}=H_{i, t} / N_{i, t}\left(s_{i, t}=S_{i, t} / N_{i, t}\right)$. Then, by aggregating, we may calculate the aggregate hiring rate $W_{P O S}=\Sigma_{i}\left(N_{i, t} / N_{t}\right) \times h_{i, t}$ and the aggregate separation rate $W N E G_{t}=\Sigma_{i}\left(N_{i, t} / N_{t}\right) \times s_{i, t}$ The sum of both rates is the worker turnover or worker reallocation rate $\left(W R_{t}=W P O S_{t}+W N E G_{t}\right)$. It gives us an idea of gross external mobility of workers in the whole economy (or, as in our case, in the sample of the survey used in the analysis).

${ }^{15}$ In addition, we have estimated a tobit model including annual and quarterly dummies and the results are quite similar. In this case, the coefficient for agreements at the firm's level is 1.671. These results are available upon request. 
ample) potentially linked to the provision of training by the firm. We have estimated a conditional fixed-effect logit to eliminate the influence of time-invariant unobserved heterogeneity. Table 6 shows the coefficient and the marginal effect of this estimation for the dummy variable of a collective agreement at the firm level. The coefficient is clearly positive and the marginal effect shows that this scope of the collective bargaining increases the probability of having training in the firm by 30 per cent. Therefore, controlling by this type of unobserved heterogeneity in fact actually increases the effect of the scope of collective bargaining on the probability of having training hours. However, this fixed-effect logit is conditional to the sample used in the estimation which is different with respect to the original sample used to estimate the probit and tobit with random effects. The original sample amounts to 24,664 while the sample used to estimate the conditional fixed-effects logit model decreases to 11,371 . In any case, the positive coefficient of this estimation supports the robustness of results.

To check the robustness of our results, we have estimated random and fixed-effects regressions on our continuous dependent variable. The results are also summarised in Table 6. As before, we have obtained positive coefficients, although they are lower than those obtained in the tobit model. In these models, the collective agreement at the firm level increases training hours around 0.26 or 0.27 hours per 100 workers per quarter, which are much lower than the original estimate for the tobit model (1.5). At any rate, as we obtain a positive coefficient, we consider the main result to be quite robust.

Thus, collective agreements at the firm level not only increase the probability of having training, but the size of training too. These results are consistent with those studies for the UK finding a positive correlation between training incidence and measures of union presence, such as union coverage for collective bargaining or union density (Booth et al., 2003; Green et al., 1999). In other words, we have the same result under a different institutional framework.

This empirical evidence supports an interpretation in terms of the Acemoglu-Pischke model. Not only is there a clear and positive influence of agreements at the firm level on a higher provision of training, but these agreements have a documented effect (Canal and Rodríguez, 2004) compressing wage structure. Therefore, we have a confirmation of the main prediction of the Acemoglu-Pischke model under the Spanish institutional settings, where collective agreements at the firm level would be a 'friction' increasing training provision by firms through their impact on wage compression ${ }^{16}$.

16 The positive effect of collective agreements at the firm level is potentially coherent with exit-voice theory, because in the Spanish institutional framework this type of agreement is the 
We would like to point out that there is a previous article (Peraita, 2001) which attempts to test the Acemoglu-Pischke model predictions for the Spanish labour market with negative results. Using data from the European Community Household Panel (ECHP), this author finds that firm-sponsored training is almost not affected by the compression of the wage structure. However, the evidence provided by Peraita (2001) does not focus on the relevance of the institutional mechanism for the causal effects identified in the Acemoglu-Pischke model. Therefore, we interpret such a negative result obtained by this author as a problem linked to the omission of variables related to the scope of collective bargaining ${ }^{17}$.

Although we are using data from firms with more than 500 workers, the estimated effect of collective agreements at the firm level is highly relevant, because this type of agreement is rather scarce for small and medium size firms.

Now we proceed to comment on other variables of interest.

Concerning the variable that measures the proportion of temporary workers with respect to the total workforce, the results confirm the negative influence on training (see Tables 3 and 5). A recent study for Spain (Albert et al., 2005) using individual data shows that workers with temporary contracts are not only less likely to be employed in training firms, but, once they are in those firms, they also have a lower probability of being chosen to participate in firm-provided training activities. In addition, research for other countries, such as Arulampalam and Booth (1998) for the UK, shows that workers with atypical contracts receive less training. Nevertheless, other researchers for the Spanish labour market (such as Tugores and Alba, 2002) find that the probability of receiving training by the firm is not related to the worker having an open-ended or a temporary contract. In any case, these authors find significant differences among different temporary contracts. Workers with training and apprenticeship contracts receive training with a higher probability than the rest of workers with a different type of temporary contract.

transmission mechanism of the voice effects of organized labour (García-Serrano and Malo, 2002). However, as we explained before, the role of these agreements is wage compression is not a crucial argument about the effects of the voice effect on training provision as in the AcemogluPischke model.

${ }^{17}$ In any case, we want to highlight the fact that the ECHP database does not contain information about which type of collective agreement applies in the firm of interviewees. 
Another relevant difference related to the dichotomy of atypical/typical workers is the distinction between full-time and part-time workers. We find that the proportion of full-time workers increases training (Tables 3 and 5). Therefore, the econometric analysis confirms that atypical contracts are, ceteris paribus, related to less training (here, a lower probability of having training or a lower amount of training hours).

The largest firms (those with more than 2,000 workers) are more likely to offer training $^{18}$ (Tables 3 and 4). However, the size does not affect the amount of training hours (Table 5).Although, these results must be understood in a context where the firm has more than 500 employees (because of the avalaible data), we do not believe that changes a lot if we consider small firms, because in Spain the collective agreement at firm level is signed above all by great firms. Note that we obtain this result using only firms with more than 500 workers.

The set of industry dummies shows that the highest training is for the energy and industrial sector followed by information technology and R $+\mathrm{D}$. Regional dummies show significant regional differences. Finally, we find an increasing time trend in having training and training hours. Also, we check if the provision of training is concentrated in some quarters, and we could confirm that this fact is no significant in our data. In addition, we have checked whether the provision of training is concentrated in some quarters, but these dummy variables are not statistically significant ${ }^{19}$.

\section{CONCLUSIONS}

Using a Spanish data we have analyzed the influence of the scope of collective bargaining on training provision by firms. As a difference with respect to the main part of previous research on training, we have not used individual data but a quarterly firms panel survey of large firms, the Encuesta de Coyuntura Laboural (ECL) or Survey of Economic Situation for the period 1997:1-2002:1.

${ }^{18}$ Black et al. (1999) support the idea that larger firms offer more training because they have lower training costs due to the larger number of employees in the training programs. However, we point out that our database only refers to firms with over 500 workers, in other words, only large firms. This limitation does not allow for an analysis about how the firm's size affects training hours.

19 These estimations are available upon request. 
This article provides additional empirical evidence about the relevance of market structure for training provision, but highlights the role of the institutional framework. Following the Acemoglu-Pischke model on training provision by firms, we have looked for 'friction' in the Spanish institutional framework of the labour market affecting wage compression as the theoretical model predicts and confirmed by previous literature concerning the Spanish labour relations system. This 'friction' is the collective agreement at the firm level, and the prediction to be tested was that firms with this type of collective agreement will have a higher level of training provision with respect to firms with above level agreements (because of the institutional framework of the Spanish labour market all workers are covered by a collective agreement, either at the firm or an above level).

The empirical analysis shows that firms with a collective agreement at the firm level have a higher probability (11 per cent higher) of developing training and a higher amount of training (1.5 hours per 100 workers per quarter) with respect to firms covered by collective agreements at above levels. As our training variable is defined as working hours lost because of training, we can state that this investment is, at least, co-financed by the firm (lost working hours is a relevant opportunity cost of training).

Therefore, we confirm that our results support the Acemoglu-Pischke model under the Spanish institutional framework, where collective agreements at the firm level are the type of labour market imperfection considered by this theoretical model to affect a higher training provision by firms through the causal channel of wage compression. Under this interpretation of the institutional framework, our results are comparable with international research about the influence of organized labour on training provision by firms.

Finally, as an interesting side result, we have found a negative effect of higher proportions of atypical contracts (either temporary or part-time contracts) on the probability of counting hours lost by training and the amount of such training hours. These results are coherent with previous literature showing that workers with atypical contracts have a lower probability of receiving training.

\section{REFERENCES}

Abellán, C.; Felgueroso, F. and Lorences, J. (1997), «La negociación colectiva en España: Una reforma pendiente», Papeles de Economía Española, nº 72, 250-260.

Acemoglu, D. and Pischke, J. S. (1998), «Why do Firms Train? Theory and Evidence», Quarterly Journal of Economics, nº 113 (1), 79-119. 
Acemoglu, D. and Pischke, J. S. (1999a), «The Structure of Wages and Investment in General Training», Journal of Political Economy, 107 (3), 539-572.

- (1999b), «Beyond Becker: Training in Imperfect Labour Markets», Economic Journal, 109, February, F112-F142.

Albert, C.; García-Serrano, C. and Herranz, V. (2005), «Firm-provided training and temporary contracts», Spanish Economic Review, n 7, 67-88.

Alba-Ramírez, A. (1994), «Formal Training, Temporary Contracts, Productivity and Wages in Spain», Oxford Bulletin of Economics and Statistics, vol. 56, $\mathrm{n}^{\circ} 2,151-170$.

Arulampalam, W. (1999), «Practitioners' Corner: A Note on Estimated Coefficients in Random Effects Probit Models», Oxford Bulletin of Economics and Statistics, 61 (4), 97-602.

Arulampalam, W. and Boоth, A. L. (1998), «Training and Labor Market Flexibility: Is There a Trade-off?», British Journal of Industrial Relations, vol. 36 (4), 521-536.

Barron, J. M.; Fuess, S. M. and Loewenstein, M. A. (1987), «Further Analysis of the Effect of Unions on Training (Union Wages, Temporary Layoffs, and Seniority)», Journal of Political Economy, vol. 95, n 3, 632-40.

Becker, G. S. (1964), Human Capital: A Theoretical and Empirical Analysis, with Special Reference to Education. New York, Columbia University Press: National Bureau of Economic Research.

Black, D. A.; Noel, B. J. and Wang, Z. (1999), «On-the-Job Training, Establisment Size, and Firm Size: Evidence for Economies of Scale in the Production of Human Capital», Southern Economic Journal, vol. 66 (1), 82-100.

Boотн, A. L. and ZoegA, G. (2004), «Is wage compression a necessary condition for firmfinanced general training?», Oxford Economic Papers 56, 88-97.

Booth, A. L.; Francesconi, M. and Zoega, G. (2003), «Unions, Work-related Training, and Wages: Evidence for British Men», Industrial and Labor Relations Review, vol. 57 (1), 68-91.

Bover, O.; Bentolila, S. and Arellano, M. (2002), «The distribution of earnings in Spain during the 1989s: the effects of skill, unemployment, and union power», in D. Cohen, T. Piketty and G. Saint-Paul (eds.), The Economics of Rising Inequalities, Oxford, CEPR and Oxford University Press, 3-53.

Canal, J. F. and Rodríguez, C. (2004), «Collective Bargaining and Within-Firm Wage Dispersion in Spain», British Journal of Industrial Relations, 42(3), 481-506.

Davis, S. J. and Haltiwanger, J. C. (1992), «Gross Job Creation, Gross Job Destruction and Employment Reallocation,» Quarterly Journal of Economics, 107 (3), 819-863.

Dolado, J. J.; Felgueroso, F. and Jimeno, J. F. (1997): «The effects of minimum bargained wages on earnings: Evidence from Spain», European Economic Review, 41: 713-721.

Duncan, G. and Stafford, F. (1980), «Do Union Members Receive Compensating Differentials?», American Economic Review, vol. 70, 355-71. 
Escobar, M. (1995), «Spain: Works Councils or Unions?», in J. Rogers and W. Streek (eds.), Works Councils: Consultation, Representation, and Cooperation in Industrial Relations, NBER-Chicago University Press, Chicago, 153-188.

Frazis, H. J.; Herz, D. E. and Horrigan, M. W. (1995), «Employer-Provided Training: Results from a New Survey», Monthly Labor Review, May, 3-17.

Fina, L.; GonzÁlez, F. and PÉrez-Infante, J. I. (2001), Negociación colectiva y salarios en España, CES: Madrdid.

Freeman, R. B. (1980), «The Exit-voice Trade-off in the Labor Market: Unionism, Job tenure, Quits, and Separations», Quarterly Journal of Economics, 94, 43-673.

García-Serrano, C. and Malo, M. Á. (2002), «Worker Turnover, Job Turnover, and Collective Bargaining in Spain», British Journal of Industrial Relations, vol. 40 (1), 69-85.

Green, F. (1993), «The Impact of Trade Union Membership on Training in Britain», Applied Economics, vol. 25, 1033-43.

Green, F.; Machin, S. and Wilkinson, D. (1999), «Trade Unions and Training Practices in British Workplaces», Industrial and Labor Relations Review, vol. 52, 2, 179-196.

JiMENo, J. F. (1992), «Las implicaciones macroeconómicas de la negociación colectiva: el caso Español», Moneda y crédito, 195, 223-281.

Jimeno, J. F. and Toharia, L. (1993), «Spanish Labour Markets: Institutions and Outcomes», 299-322, in J. Hartog and J. Theeuwes (eds.), Labour Market Contracts and Institutions, Elsevier Science Publishers.

Kennedy, S.; Drago, R.; Sloan, J. and Wooden, M. (1994), «The effect of Trade Unions on the Provision of Training: Australian Evidence», British Journal of Industrial Relations, vol. 32, 565-580.

LindBeck, A. et al. (1993), «Options for Economic and Political Reforms in Sweden», Economic Policy, 18, 219-246.

LyNCH, L. (1992), «Private Sector Training and the Earnings of Young Workers», American Economic Review, vol. 82, 299-312.

Malo, M. Á. (2005), «A Political Economy Model of Workers' Representation: The Case of Union Elections in Spain», European Journal of Law and Economics, 19, 115-134.

Martínez Lucio, M. (1998), «Spain: Regulating Employment and Social Fragmentation», in Anthony Ferner and Richard Hyman (eds.), Changing Industrial Relations in Europe, Blackwell Publishers, Oxford, 426-458.

Martínez-Lucio, M. and Stuart, M. (2003), «International briefing 13: Traning and development in Spain-the politics of modernisation», International Journal of Training and Development, 7: 1, 67-77.

Mincer, J. (1983), «Union Effects: Wages, Turnover and Job Training», in J. D. Reid Jr. (ed), New Approach to Labor Unions, Research in Labor Economics, Supplement 2, Greenwich, Conn: JAI Press. 
OCDE (1999), Employment Outlook, Paris.

Osterman, P. (1995), «Skill, Training, and Work Organization in American Establishments», Industrial Relations, vol. 34, $\mathrm{n}^{\circ}$ 2, 125-146.

Peraita, C. (2001), «Testing the Acemoglu-Pishcke model in Spain», Economics Letters, vol. 72, 107-115.

RaInBIRD, H. (1990), Training Matters, Union Perspectivas on Restructuring and Training, Blackwell, Oxford.

Rigby, M. (2002), «Spanish Trade Unions and the Provision of Continuous Training», Employee Relations, vol. 24, $\mathrm{n}^{\circ}$ 5, 500-515.

RodríGuez, C. (1996), «Determinantes de la afiliación sindical en España», Moneda y Crédito, 203, 149-174.

- (2001), «Wage dispersion within firms and collective bargaining in Spain», Economics Letters, 72, 381-386.

RyAN, P. (1991), «Information costs, training quality and trainee exploitation», draft paper, Cambridge University.

Tugores, M. and Alba, A. (2002), «Estudio microeconómico sobre la formación continua en España. 1992-2002», Economía Industrial, nº 348.

Veum, J. (1995), «Sources of Training and Their Impact on Wages», Industrial and Labor Relations Review, vol. 48, 812-26. 
Table 1. Variables: Definitions and Summary Statistics

\begin{tabular}{|c|c|c|c|c|c|c|c|}
\hline & \multirow[b]{2}{*}{ Definition } & \multicolumn{2}{|c|}{ All firms } & \multicolumn{2}{|c|}{$\begin{array}{l}\text { With Coll. Agr. at } \\
\text { firm level }\end{array}$} & \multicolumn{2}{|c|}{$\begin{array}{l}\text { W/O Coll. Agr. at } \\
\text { firm level }\end{array}$} \\
\hline & & Mean & S. D. & Mean & S. D. & Mean & S. D. \\
\hline Training & Training hours per 100 worker & 59.66 & 215 & 104.3 & 292 & 37.1 & 158 \\
\hline Dtraining & 1 if training is $>0$; otherwise $=0$ & 0.279 & 0.44 & 0.36 & 0.48 & 0.23 & 0.42 \\
\hline $\begin{array}{l}\text { Full-time } \\
\text { workers }\end{array}$ & Full-time workers/total workers & 0.900 & 0.18 & 0.94 & 0.18 & 0.87 & 0.19 \\
\hline $\begin{array}{l}\text { Temporary } \\
\text { workers }\end{array}$ & Temporary workers/total workers & 0.293 & 0.31 & 0.15 & 0.31 & 0.36 & 0.33 \\
\hline $\begin{array}{l}\text { Coll.Ag. } \\
\text { Firm Level }\end{array}$ & $\begin{array}{l}1 \text { if there is a firm level agreement; } \\
\text { otherwise = cero. }\end{array}$ & 0.335 & 0.47 & - & - & - & - \\
\hline Turnover & Job turnover rate $(*)$ & 3.095 & 8.57 & 1.486 & 3.5 & 3.907 & 1.01 \\
\hline $\begin{array}{l}\text { Industry } \\
\text { and energy }\end{array}$ & Industry dummy & 0.238 & 0.42 & 0.46 & 0.49 & 0.12 & 0.33 \\
\hline Building & Industry dummy & 0.022 & 0.14 & 0.01 & 0.09 & 0.02 & 0.16 \\
\hline $\begin{array}{l}\text { Trade and } \\
\text { hospitality }\end{array}$ & Industry dummy & 0.126 & 0.33 & 0.11 & 0.31 & 0.13 & 0.34 \\
\hline Transport & Industry dummy & 0.084 & 0.27 & 0.19 & 0.39 & 0.02 & 0.16 \\
\hline Banking & Industry dummy & 0.100 & 0.29 & 0.03 & 0.17 & 0.13 & 0.34 \\
\hline $\mathrm{R} \& \mathrm{D}$ & Industry dummy & 0.016 & 0.12 & 0.00 & 0.07 & 0.02 & 0.14 \\
\hline $\begin{array}{l}\text { Social } \\
\text { Services }\end{array}$ & Industry dummy & 0.415 & 0.49 & 0.18 & 0.39 & 0.52 & 0.49 \\
\hline Region1 & $\begin{array}{l}1 \text { if firm is located in Castilla-León and } \\
\text { Castilla la Mancha; otherwise = } 0\end{array}$ & 0.066 & 0.24 & 0.06 & 0.23 & 0.06 & 0.25 \\
\hline Region2 & $\begin{array}{l}1 \text { if firm is located in Galicia. Asturias. } \\
\text { Cantabria and Basque Country ; } \\
\text { otherwise }=0\end{array}$ & 0.115 & 0.31 & 0.15 & 0.35 & 0.09 & 0.29 \\
\hline Region3 & $\begin{array}{l}1 \text { if firm is located in Madrid; otherwise } \\
=0\end{array}$ & 0.244 & 0.42 & 0.24 & 0.43 & 0.24 & 0.42 \\
\hline Region4 & $\begin{array}{l}1 \text { if firm is located in Catalonia. Valen- } \\
\text { cia and Murcia; otherwise }=0\end{array}$ & 0.243 & 0.42 & 0.21 & 0.41 & 0.25 & 0.43 \\
\hline Region5 & $\begin{array}{l}1 \text { if firm is located in Andalucía and } \\
\text { Extremadura; otherwise }=0\end{array}$ & 0.174 & 0.37 & 0.16 & 0.37 & 0.17 & 0.38 \\
\hline Region6 & $\begin{array}{l}1 \text { if firm is located in Aragón. La Rioja } \\
\text { and Navarra; otherwise }=0\end{array}$ & 0.094 & 0.29 & 0.10 & 0.30 & 0.08 & 0.28 \\
\hline Region7 & $\begin{array}{l}1 \text { if firm is located in Balearic and } \\
\text { Canary Islands; otherwise }=0\end{array}$ & 0.063 & 0.24 & 0.05 & 0.22 & 0.06 & 0.25 \\
\hline
\end{tabular}


Table 1 (cont.). Variables: Definitions and Summary Statistics

\begin{tabular}{|c|c|c|c|c|c|c|c|}
\hline \multirow[b]{2}{*}{$\begin{array}{l}\text { Firmsize } \\
<1001\end{array}$} & \multirow[b]{2}{*}{$\begin{array}{l}1 \text { if firm has } 1000 \text { or less employees; } \\
\text { otherwise }=0\end{array}$} & \multicolumn{2}{|c|}{ All firms } & \multicolumn{2}{|c|}{$\begin{array}{l}\text { With Coll. Agr. at } \\
\text { firm level }\end{array}$} & \multicolumn{2}{|c|}{$\begin{array}{l}\text { W/O Coll. Agr. at } \\
\text { firm level }\end{array}$} \\
\hline & & 0.646 & 0.47 & 0.64 & 0.47 & 0.64 & 0.47 \\
\hline $\begin{array}{l}\text { Firmsize } \\
1001-2000\end{array}$ & $\begin{array}{l}1 \text { if firm has 1001-2000 employees; } \\
\text { otherwise }=0\end{array}$ & 0.237 & 0.42 & 0.23 & 0.42 & 0.23 & 0.42 \\
\hline $\begin{array}{l}\text { FiFirmsize } \\
3>2000\end{array}$ & $\begin{array}{l}1 \text { if firm has more than } 2000 \text { employ- } \\
\text { ees; otherwise = } 0\end{array}$ & 0.117 & 0.32 & 0.12 & 0.32 & 0.11 & 0.31 \\
\hline Time trend & $\begin{array}{l}1 \text { if date is the first quarter } 1997 . \\
2 \text { if date is the second quarter } 1997 . \\
\text { and so on... until } 21 \text { if date is the first } \\
\text { quarter } 2002 \text {. }\end{array}$ & - & - & - & - & - & - \\
\hline
\end{tabular}

(*) The job turnover rate is defined as in García-Serrano and Malo (2002), following the indicators for job creation and destruction proposed by Davis and Haltiwanger (1992).

Table 2. Hours of training per 100 workers in a quarter and characteristics of the firms

\begin{tabular}{|l|c|c|c|c|}
\hline & Zero hours & $<100$ & $\geq 100$ & TOTAL \\
\hline Size of the firm (Average) & 1.254 & 1.145 & 1.344 & 1.247 \\
\hline$\%$ Full-time Workers & $88.2 \%$ & $93.3 \%$ & $96.7 \%$ & $90.03 \%$ \\
\hline$\%$ Temporary Workers & $31.8 \%$ & $26.9 \%$ & $16.9 \%$ & $29.3 \%$ \\
\hline Main activity of the firm: & & & & \\
-Industry and energy & $20.3 \%$ & $25.8 \%$ & $42,0 \%$ & $23.8 \%$ \\
-Building & $2.2 \%$ & $2.1 \%$ & $2.4 \%$ & $2.2 \%$ \\
-Trade and hotel business & $15 \%$ & $7.6 \%$ & $4.5 \%$ & $12.6 \%$ \\
-Transports and communications & $8.4 \%$ & $5,0 \%$ & $13.1 \%$ & $8.4 \%$ \\
-Banking & $9.8 \%$ & $10.1 \%$ & $10.7 \%$ & $10.0 \%$ \\
-R\&D & $1.7 \%$ & $0.5 \%$ & $2.3 \%$ & $1.6 \%$ \\
-Social services & $42.5 \%$ & $48.8 \%$ & $25.1 \%$ & $41.5 \%$ \\
\hline Collective Agreement: & & & & \\
-Firm level. & $29.6 \%$ & $36.6 \%$ & $53.8 \%$ & $33.6 \%$ \\
-Higher level. & $70.4 \%$ & $63.4 \%$ & $46.2 \%$ & $66.4 \%$ \\
\hline Observations and percentages & $17.786(72.1 \%)$ & $4.000(16.2 \%)$ & $2.878(11.7 \%)$ & $24.664(100 \%)$ \\
\hline
\end{tabular}


Table 3. Random-effects probit model on the probability of having training in the firm

\begin{tabular}{|l|r|r|}
\hline \multicolumn{1}{|c|}{ Independent variables } & Coeficients & Std. Err. \\
\hline Constant & -1.613 & 0.234 \\
Time trend & 0.019 & 0.002 \\
Full-time workers & 0.856 & 0.169 \\
Temporary workers & -0.350 & 0,736 \\
Coll.Ag.Firm Level & -0.002 & 0.083 \\
Turnover & $-0,137$ & 0.050 \\
Building & -0.967 & 0.002 \\
Trade and hotel business & -0.108 & 0.130 \\
Transport & -0.521 & 0.112 \\
Banking & -0.815 & 0.090 \\
R\&D & -0.235 & 0.089 \\
Social Services & -0.069 & 0.152 \\
Region2 & -0.495 & 0.087 \\
Region3 & -0.407 & 0.109 \\
Region4 & -0.610 & 0.112 \\
Region5 & -0.374 & 0.099 \\
Region6 & -0.765 & 0.103 \\
Region7 & -0.137 & 0.107 \\
Firmsize<1001 & -0.189 & 0.105 \\
Firmsize1001-2000 & 24.664 & 0.067 \\
\hline No observation & 0.742 & 0.067 \\
Rho* & $656.9(\chi 2(19))$ & \\
Wald & -007 \\
\hline
\end{tabular}

* Rho is the proportion of the variance due to individual effects.

Source: ECL, 1997:1-2001:1

Table 4. Probit model: Marginal effects

\begin{tabular}{|l|c|l|}
\hline \multicolumn{1}{|c|}{ Independent variables } & Mean & Std. Err. \\
\hline Full-time workers & 0.133 & 0.029 \\
\hline Temporary workers & -0.054 & 0.011 \\
\hline Coll.Ag.Firm Level & 0.114 & 0.025 \\
\hline Turnover & -0.000 & 0.000 \\
\hline Firmsize $<1001$ & -0.021 & 0.004 \\
\hline Firmsize1001-2000 & -0.029 & 0.006 \\
\hline
\end{tabular}

Note: Marginal effects have been estimated following Arulampalam (1999). 
TRAINING PROVISION BY FIRMS AND THE SCOPE OF COLLECTIVE BARGAINING: AN EMPIRICAL ANALYSIS USING A LARGE FIRMS PANEL FROM SPAIN

Table 5. Random-effects tobit model on the amount of training hours in the firm

\begin{tabular}{|c|c|c|}
\hline Independent variables & Coeficients & Std. Err. \\
\hline Constant & -6.370 & 0.472 \\
\hline Time trend & 0.042 & 0.005 \\
\hline Full-time workers & 2.976 & 0.397 \\
\hline Temporary workers & -0.250 & 0.187 \\
\hline Coll.Ag.Firm Level & 1.463 & 0.118 \\
\hline Turnover & 0.003 & 0.005 \\
\hline Building & -2.125 & 0.306 \\
\hline Trade and hotel business & -2.648 & 0.221 \\
\hline Transport & -0.156 & 0.183 \\
\hline Banking & -2.727 & 0.215 \\
\hline$R \& D$ & -1.473 & 0.409 \\
\hline Social Services & -2.429 & 0.151 \\
\hline Region2 & -0.348 & 0.205 \\
\hline Region3 & -0.902 & 0.186 \\
\hline Region4 & -0.139 & 0.206 \\
\hline Region5 & -0.192 & 0.195 \\
\hline Region6 & -0.141 & 0.235 \\
\hline Region7 & -0.639 & 0.234 \\
\hline Firmsize $<1001$ & 0.464 & 0.139 \\
\hline Firmsize 1001-2000 & 0.010 & 0.145 \\
\hline $\mathrm{N}^{\circ}$ observation & 24.664 & \\
\hline Censored & 17.786 & \\
\hline Uncensored & 6.878 & \\
\hline Rho * & 0.647 & 0.007 \\
\hline Wald & $1.412(\chi 2(19))$ & \\
\hline
\end{tabular}

* Rho is the proportion of the variance due to individual effects.

Source: ECL, 1997:1-2001:1 
Figure 6. Summary of other estimations (S.E. between brackets)

\begin{tabular}{|c|c|c|}
\hline Independent variables & Mean & Std. Err. \\
\hline \multicolumn{3}{|c|}{ Conditional Fixed-Effects Logit * } \\
\hline Coll.Ag.Firm Level & $\begin{array}{r}1.377 \\
(0.112)\end{array}$ & $\begin{array}{r}0.305 \\
(0.057)\end{array}$ \\
\hline \multicolumn{3}{|c|}{ GLS Estimation with Random Effects } \\
\hline Coll.Ag.Firm Level & $\begin{array}{r}0.272 \\
(0.040)\end{array}$ & \\
\hline \multicolumn{3}{|c|}{ OLS Estimation with Fixed-Effects } \\
\hline Coll.Ag.Firm Level & $\begin{array}{r}0.258 \\
(0.044)\end{array}$ & \\
\hline
\end{tabular}

* Number of cases: 11,371

Source: ECL, 1997:1-2001:1

Figure 1. Hours of training per 100 workers and establishment's size

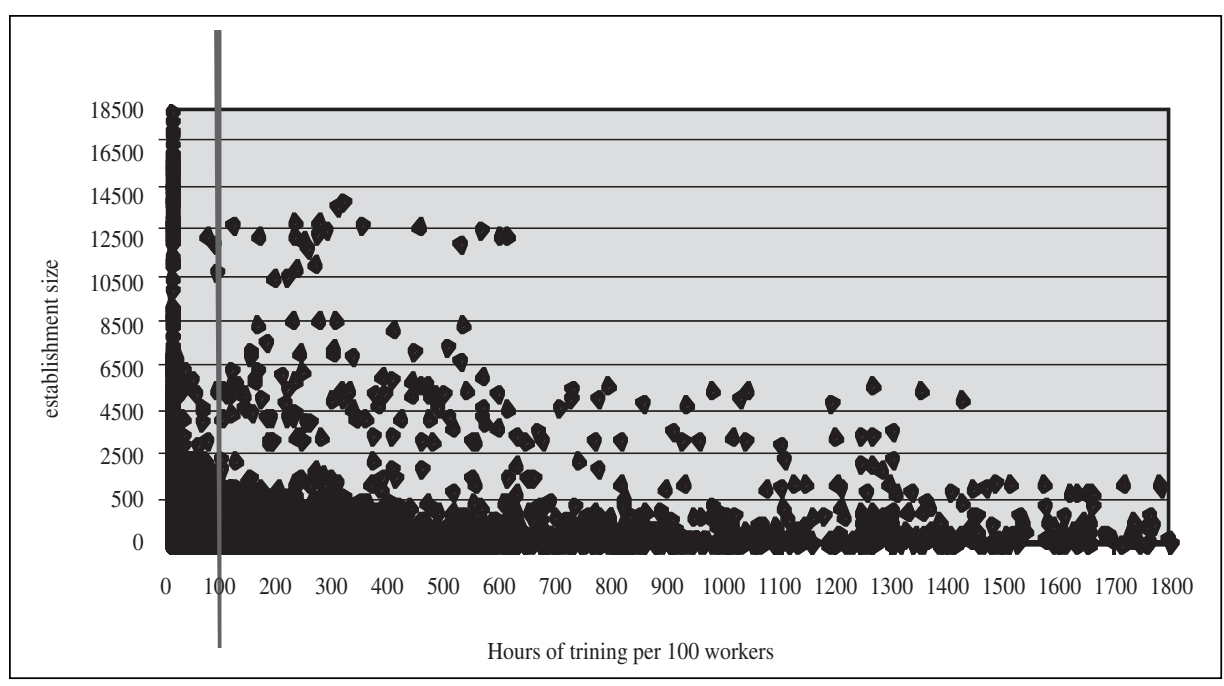

